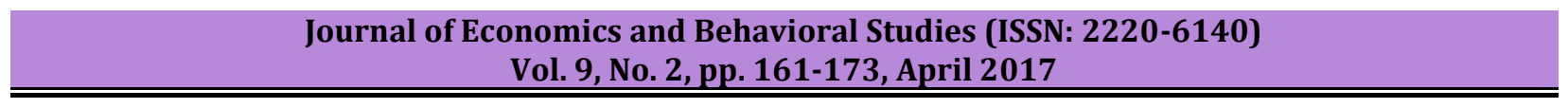

\title{
Factors Influencing Competitiveness of Small and Medium Enterprises (SMEs) in Nairobi County, Kenya
}

\author{
Anne Irungu ${ }^{1}$, Robert Arasa ${ }^{2 *}$ \\ ${ }^{1}$ Catholic University of Eastern Africa, Kenya \\ ${ }^{2}$ Machakos University, Kenya \\ rarasa4@gmail.com
}

\begin{abstract}
The purpose of this study was to examine factors influencing firm competitiveness among the Small and Medium Enterprises in Nairobi, Kenya. Specifically the study set out to examine the influence of strategic leadership, technology, resources and organization culture on competitiveness of Small and Medium Enterprises in Nairobi. The study adopted a descriptive research design. The study population comprised of SMEs in Nairobi which fall within the top 100 SMEs in Kenya. There are 79 SMEs from Nairobi County in the Top 100 SMEs in Kenya. A sample size of 25 SMEs which represented 30\% of the target population was selected through stratified random sampling. The stratification was based on five business sector categories (real estate, supplies, services, distribution and manufacturing). The study utilized primary data which was collected from top management employees through the use of questionnaire. Data was analyzed using both descriptive and inferential statistics. Correlation analysis was employed to aid in establishing the nature and strength of the relationships between variables of interest. Correlation analysis results indicate that strategic leadership, adoption of relevant technology, resources availability and organization culture has a positive and significant relationship with firm competitiveness. The study concludes that sustainable competitive advantage of the firm stems from effective strategic leadership, adoption of technology, resources availability and effective organization culture. The study recommends that SMEs should embrace various competitive strategies to remain relevant in the market and achieve the required competitiveness. The SMEs managers should embrace strategic leadership practices, benchmark on best practices to ensure constant touch with their customers, embrace adoption of appropriate technology towards realizing higher levels of efficiency and effectiveness, ensure optimal utilization of resources, and cultivate a good balance between the organization culture and the organization processes so as to enhance competitive advantage. This study was confined to factors influencing organizational competitiveness of small and medium enterprises within Nairobi County. Other studies could be pursued in terms of expanding the geographical setting and taking recognition of other variables that could intervene and or moderate the investigated relationship.
\end{abstract}

\section{Keywords: Competitiveness, SMEs, Leadership, Technology, Resources, Culture}

\section{Introduction}

Competitiveness is a characteristic which allows a business undertaking to be successful when it competes with other business undertakings (Ireland and Hitt, 1999). Hakansson and Snehota (1989) argue that 'no business is an island', indicating that companies are involved in long-term relationships. Organizations must understand how changes in their environment are unfolding and should actively look for opportunities to exploit their strategic abilities, adapt and seek improvements in every area of the business, building on awareness and understanding of current strategies and successes. Organizations must be able to act quickly in response to opportunities and barriers in the industry (Abishua, 2010). Competitiveness does not generally refer to a win or lose situation, but rather a comparative advantage in a specific area (Garelli, 2006). While there are a number of policies which can be implemented to improve the competitiveness of a financial system, at its foundation is the competitiveness of firms. A company achieves competitive advantage whenever it has some type of edge over rivals in attracting buyers and coping with competitive forces. There are many routes to competitive advantage, but they all involve giving buyers what they perceive as superior value compared to the offerings of rival sellers. When focusing on the competitiveness of individual financial institutions, there are a number of things which represent competitiveness. The two main items used to measure performance are the firms market share within the particular industry in which it operates and its profitability. Profitability is then used to measure the company return on capital employed hence value to its 
shareholders. Kaplan and Norton (2001) introduced the balanced score card as a more realistic measure of performance. In addition to the financials the tool also considers customer issues, learning and growth within the organization and internal business processes. Internal business process is the path to achieving strong financial results and superior customer satisfaction.

Small and Medium Enterprises Sector: Middle market companies represent more than a third of American jobs and more than $\$ 9$ trillion in annual revenue. The average employment growth in 2012 for middle market companies was $2.7 \%$, compared with $2.1 \%$ for large firms. The services industry companies in healthcare or the restaurant business, for instance showed the most growth, adding approximately 950,000 employees. While small businesses struggled to pay the lease or turn a profit, and large corporations laid off thousands of workers to satisfy shareholders, medium-size companies scooped up top talent and got creative (Caldwell, 2013). Aremu and Adeyemi (2011) in their study in Nigeria noted that the SME sector is the main driving force behind job creation, poverty reduction, wealth creation, income distribution and reduction in income disparities. In Kenya, SMEs is a critical sub-sector towards the realization of the Kenya Vision 2030 (longterm development blueprint for the country). The aim of Kenya Vision 2030 aims at transforming Kenya into newly-industrializing, middle income country providing a high quality of life to all its citizens in a clean and secure environment. In other words the vision aspires to meet the Sustainable Development Goals (SDGs) for Kenyans. The Vision is anchored on three key pillars: Economic; Social; and Political Governance. The medium sized enterprises are considered key in the implementation of flagship projects that will help achieve this vision (Republic of Kenya, 2009). According to the Economic Survey (Republic of Kenya, 2012), the SME sector contributed $79.8 \%$ of new jobs created in that year in Kenya. It is also important to note that the Kenya's development plans for the 1989-1993, 1994-1996 and 1997-2001 periods put special emphasis on the contribution of small and medium size enterprises in the creation of employment in the country.

According to the statistics provided by Nairobi county licensing office there were 825 SMEs in 2014 based in Nairobi County operating in service and manufacturing sectors. The contribution of SMEs to job creation in the country is regarded as immense. Analysis by county shows that Nairobi County recorded a 5.4 increase in job creation in 2011 in the SMEs sector (Republic of Kenya, 2012). Like in any other part of the country SMEs in Nairobi have high mortality rates with most of them not surviving to see beyond their third anniversaries (Republic of Kenya, 2009). The top 100 SMEs survey was first launched in Kenya in 2008, in Uganda in 2009 and in Tanzania in 2010. Top100 SMEs survey seeks to identify the country's fastest growing medium sized companies, showcase their business excellence and highlight some of the country's most successful entrepreneurship stories. Kenya's Top 100 mid-sized companies Survey is an initiative of KPMG Kenya and Nation Media Group. The Survey seeks to identify Kenya's fastest growing medium sized companies in order to showcase business excellence and highlight some of the country's most successful entrepreneurship stories. Essentially, a top $100 \mathrm{SME}$ is one which ranks ahead of its peers in terms of revenue growth, profit growth, returns to shareholders and cash generation/liquidity. A Top 100 company has succeeded in progressively growing its market position in the industries in which it operates and over time; the growth translate into both returns for its shareholders and a fairly sound financial position. The top 100 SMEs fall into five categories: manufacturing, supplies, services, distribution and real estate.

Statement of the Problem: The Small and Medium Enterprises (SMEs) sector has an important role to play in developing economies, poverty alleviation and job creation. There is notable growth in the SMEs sector in terms of number of enterprises and products offered across the various subsectors. This growth intensifies the competitive environment for the players. For an organization to survive, achieve and sustain competitive advantage in such an environment, it has to differentiate itself in terms of cost and quality of products and services. Given the increasing intensity of competition and the demands and expectations of customers and potential customers for quality products and services, organizations day in day out are strategizing to always be within or beat the competition. However, the achievement of competitiveness can be explained by various factors. According to Thompson et al. (2012), many factors may explain an organization's performance and thus competitiveness. Some of these factors could be attributed to the high mortality rates of SMEs in the region, with most of them not surviving beyond the third year after taking off. 
Empirical research has indicated that in competitive and rapidly changing market environments, firms need to possess capabilities that are dynamic to sustain their competitive advantage (Ambrosini, Bowman and Collier, 2009; Ray, Barney and Muhanna, 2004). Some of the notable studies that have been conducted on SMEs both within Kenya and internationally include a study by Qiuhong and Tiorini, (2009) who focused on strategic Management in East Asia SMEs, Aremu and Adeyemi (2011) who examined Small and Medium Scale Enterprises as A Survival Strategy for Employment Generation in Nigeria and, Nzitunga (2015) whose study focused on Strategic Development for Manufacturing Small \& Medium Enterprises (SMEs) in Namibia. There seem to be little attention towards understanding factors that influence competitiveness of SMEs in Kenya, hence this study. This study set out to examine factors influencing organizational competitiveness among the Small and Medium Enterprises in Nairobi County, Kenya. Specifically the study aimed at examining the influence of strategic leadership, adoption of technology, resource availability and organization culture on competitiveness of Small and Medium Enterprises operating in Nairobi.

\section{Literature Review}

Theoretical Framework: According to Thompson et al. (2012), there is a tight connection between competitive advantage and profitability. The quest for sustainable competitive advantage always ranks high in the crafting of strategic framework for the organization. A brief discussion of relevant theories is done below.

Resource-Based View Theory: From a resource based view of the firm, it is of high importance to take a close look at the internal organization of a company and its resources in order to understand how competitive advantage is determined within firms (Wernerfelt, 1984). In other words, the central premise of RBV addresses the fundamental question of why firms are different and how firms achieve and sustain competitive advantage by deploying their resources (Kostopoulos et al., 2002). The resource based perspective of firms is based on the concept of economic rent and the notion of an organization as a collection of capabilities (Kay, 2000). Whereas traditional strategy models focus on the organization's external competitive environment, the RBV accentuates the need for a fit between the external market context in which a firm operates and its internal capabilities. From this perspective the internal environment of an organization, in terms of its resources and capabilities, is the critical factor for the determination of strategic action (Hunt \& Derozier, 2004).

The original idea of viewing a firm as a bundle of resources can be traced back to Penrose (1959), who argues that it is the heterogeneity, not the homogeneity, of the productive services available from its resources that give each company its unique character. The view of the firm's resources heterogeneity is the basis of the RBV and was advanced by Wernerfelt (1984), suggesting that the evaluation of companies in terms of their disposable resources could lead to different insights from traditional perspectives that view competitive advantage as a rather external paradigm and argue that the alignment of a firm to its external environment is the main determining factor for a firm's profitability (Porter, 1985). Barney (1991) developed a framework for the identification of the properties of firm resources needed for the generation of a sustainable competitive advantage. The properties include whether resources are valuable, rare among a firm's current and potential competitors, imitable, and non-substitutable. If resources have these characteristics they can be seen as strategic assets. Subsequently, this notion has been adopted by many researchers (Amit \& Schoemaker, 1993; Peteraf, 1993) and expanded to include the properties of resource durability, nontradability, and idiosyncratic nature of resources.

The RBV can be depicted as an "inside out" process of strategy formulation. A central thrust is the contribution of core competencies as strategic assets, which will be the continuing source of new products and services through whatever future developments may take place in the market, which by their nature, are not known (Connor, 2002). The emphasis of the RBV approach to strategic management decision-making is on the strategic capabilities as basis for superiority of the firm rather than attempting to constantly ensure a perfect environmental fit. Resources are the specific physical, human, and organizational assets that can be 
used to implement value-creating strategies. Capabilities present the capacity for a team of resources to perform a task or activity (Grant, 1991). In other words, capabilities present complex bundles of accumulated knowledge and skills that are exercised through organizational processes, which enable companies to coordinate their activities and make use of their assets (Day, 1994). The resource-based theory postulates that from the principle that the source of firms competitive advantage lies in their internal resources, as opposed to their positioning in the external environment. Barney (1995) argues that competitive advantage depends on the unique resources and capabilities that a firm possesses. The resource-based view of the firm facilitates managers to predict the potential of certain types of resources owned and controlled by firms to generate competitive advantage and eventually superior firm performance (Ainuddin et al., 2007).

Strategic Leadership Theory: The essence of strategic leadership involves the capacity to learn, the capacity to change and managerial wisdom (Boal \& Hooijberg, 2001). Strategic leadership theories are "concerned with the leadership of organizations and are marked by a concern for the evolution of the organization as a whole, including its changing aims and capabilities" (Selznick, 1984). According to Boal and Hooijberg (2001) strategic leadership focuses on the people who have overall responsibility for the organization and includes not only the head of the organization but also members of the top management team. Activities associated with strategic leadership include making strategic decisions, creating and communicating vision of the future, developing key competences and capabilities, developing organizational structures, processes and controls; sustaining effective organizational cultures and infusing ethical value systems into the organization (Hunt, 1991). Strategic leaders with cognitive complexity would have a higher absorptive capacity than leaders with less cognitive complexity. To the extent that these leaders also have a clear vision of where they want their organization to go the absorptive capacity will have a greater focus. That is, strategic leaders look at the changes in the environment of their organization and then examine those changes in the context of their vision (Boal \& Hooijberg, 2001).

The trait theory reinforces this line of thought. It assumes that people inherit certain qualities or traits make them better suited to leadership. These qualities shape leader effectiveness in terms of realization of the set strategic objectives. On the other hand participative leadership theories suggest that the ideal leadership style is one that takes the input of others into account. This style of leadership has potential for enhancing commitment, collaboration, support and smooth execution of planned tasks and hence successful business performance. Contingency theory recognizes existence of various situational variables which best predict the most appropriate or effective leadership style to fit the particular circumstances for organizational effectiveness. All these theories are deemed relevant to this study as they highlight the contribution of leadership in business success. The theory also emphasizes that the environment turbulence can also be maintained through strategic leadership.

Diffusion of Innovation (DOI): Rogers' (1995) Diffusion of Innovation (DOI) theory is another popular model used in information systems research to explain user adoption of new technologies. Rogers defines diffusion as 'the process by which an innovation is communicated through certain channels over time among the members of a social society' (Rogers, 1995). Also Rogers (2003) makes another attempt to define an innovation as an idea, practice, or object, which is perceived as new by an individual or an organization. The theory considers a number of attributes associated with technological innovations and which are believed to influence the rate of widespread adoption of the innovations. These attributes are relative advantage, compatibility, complexity, trailability, observability, and security/confidentiality.

Leadership and performance: Leon (2010) contends that organizational culture and leadership styles have a link and both play an important role in determining organizational effectiveness. Arham (2014) investigated the impact of leadership behaviors on the performance of services SMEs in Malaysia. 193 owners and top managers of services SMEs in Malaysia participated in the study. The results revealed that there were significant relationships between different leadership behaviors and organizational performance of services SMEs and transformational leadership contributed more significantly to the performance of SMEs than transactional leadership behavior. These findings imply that leadership practices are among the key factors 
that influences SMEs performance. Ali, Elmi and Mohamed (2013) investigated the relationship between leadership behavior and employee performance in Mogadishu-Somalia. The study employed both descriptive and correlation research design to establish the nature of the relationships. The study findings revealed the existence of statistically significant positive relationship between leadership behavior and employee performance. A study by Zumitzavan and Udchachone (2014) examined the relationship between the demographics of respondents, leadership styles, organizational innovation, and organizational performance. Results of this study show that leadership styles do have an influence on organizational performance. Shafie, Baghersalimi and Barghi (2013) investigated the relationship between leadership style and performance in the Real Estate Registration in Tehran province. Using a descriptive correlation method, the study results showed that development-oriented and pragmatic- oriented leadership style has a positive impact on employee performance, transformational leadership style had a higher association with performance, pragmatic leadership proved more successful in stationary environment and more unsuccessful in the dynamic environment than transformational leadership. Laissez-faire leadership led to chaos in the organization. Koech and Namusonge (2012) investigated the effects of leadership styles on organizational performance of state-owned corporations in Kenya by looking at laissez-faire, transactional and transformational leadership styles. The descriptive study targeted the perceptions of middle and senior managers in thirty state-owned corporations using questionnaires. From the findings, correlations of 0.518 to $0.696, \mathrm{P}<.05$ was established between the transformational-leadership factors and organizational performance; correlations of 0.219 to $0.375, \mathrm{P}<.05$ was established between the transactional-leadership behaviors and organizational performance was laissez-faire leadership style was not significantly correlated to organizational performance.

Technology and Competitiveness: Information technology has the potential of improving operational efficiency and effectiveness. As is the case with all technologies, small businesses are slower than large ones to adopt new ICTs (OECD, 2004). Use of ICT increases the tendency of companies to perform better in market due to easier differentiation of products and services. Ollo-Lopez and Aramendia-Muneta (2012) stated that ICT adoption seems to have a positive effect on productivity, directly as well as indirectly, depending on the sectors. Further, the use of e-mail, e-commerce, and social media network has significantly cut down on the physical transportation involved in sending mail, banking, advertising and buying goods (Manochehri, AlEsmail and Ashrafi, 2012). According to Brynjolfsson and Hitt (1996), ICTs can enhance enterprise performance through indirect cost savings such as labor costs and increased labor productivity, and direct cost reduction of firm's input such as information costs. On top of these short-run impacts of ICT adoption in the production process, the use of ICTs in the transaction process can foster input and output market expansion. However, in the long run, ICT may have an even bigger impact as it can completely restructure the production process and transaction methods, increase flexibility and improve outputs.

Adeosun et al. (2009) state that the use of ICT enables strategic management, communication, collaboration, information access, decision making, data management and knowledge management in organizations. ICT can provide powerful strategic and tactical tools for organizations, which, if properly applied and used, could bring great advantages in promoting and strengthening their competitiveness (Buhalis, 2004). The use of ICT can assist to lower coordination cost and increase outsourcing in organizations. Ramsey et al. (2003) noted that organizations generally stand to gain from ICT in areas such as reduced transaction costs, information gathering and dissemination, inventory control, and quality control. Mutula and Van Brakel (2006) noted that ICTs, especially the internet, have a significant impact on the operations of SMEs by facilitating their access to global markets, enabling them to sell to international customers, and to compete favorably with large corporations. ICT has the potential to reduce the impacts of distance, reduce transaction costs, be used in information gathering and dissemination, inventory control, and quality control. Information and Communication Technology can enable SMEs to participate in the regional and international markets which are strategic for competitiveness, growth and further development.

Resources and Competitiveness: The resource-based view focuses primarily on the resources and capabilities that a company has and only secondarily on the industries/markets in which it operates. The 
proponents of this thought argue that organizations develop unique resources and capabilities, which becomes the ultimate source of competitive advantage. Most basic resource is heterogeneity, which assumes that at least some resources and capabilities are different across firms (Barney, 2011). The pioneer on the subject, Penrose (1959), describes better than any other researcher the role resources play in firm success. The most salient characteristic of the Resource-based perspective is the focus on the firm's internal strengths, a view that is connected, mostly, to the seminal work of Penrose (1959). Resources are classified in many ways, but the most common classification is based on three categories: tangible, intangible and capabilities. Grant (2011) identified six categories. Williamson (2009) identified physical capital resources, human capital resources, organizational capital resources, financial resources, technological and reputation. What is more, resources have to possess some requisites if they are meant to be sources of competitive advantages. Barney (2011) found that resources include, among others, capital equipment, skills of individual employees, reputation, and brand names. Grant (2011) wrote that the firm's resources, capabilities, and strategies are thought to impact performance. Resources, to him, are the source of a firm's capabilities, whereas capabilities are the main source of competitive advantages. Ngugi, Gakure, Were, Ngugi and Kibiru (2012) examined the influence of intellectual capital and growth of small and medium enterprises in Kenya. Findings of this study indicated that management's technical skills influenced the growth of small and medium enterprise.

Organization Culture and Competitiveness: Schein (2010) notes that a strong organizational culture has generally been viewed as a conservative force. He argues that just because a strong organizational culture is fairly stable does not mean that the organization will be resistant to change. Chittithaworn et al. (2011) studying factors affecting business success of SMEs in the manufacturing sector in Thailand among other findings, established that ways of doing business significantly affect performance. The organizational culture stands out as one of the components that are important to sustaining performance, and competitive advantage, and a good reason for becoming a great company. A study by Shahzad et al. (2012), based on a critical analysis of existing literature indicates that organizational culture has deep impact on the variety of organizations process, employees and its performance. Committed employees, who also have the same norms and value as per organizations have, can increase the performance toward achieving the overall organization goals.

Conceptual Framework: The inter-relationships which form the basis upon which the study objectives are founded are captured in the conceptual framework model as reflected in Figure 1 below.

\section{Figure 1: Conceptual Framework} Independent Variables

Dependent Variable

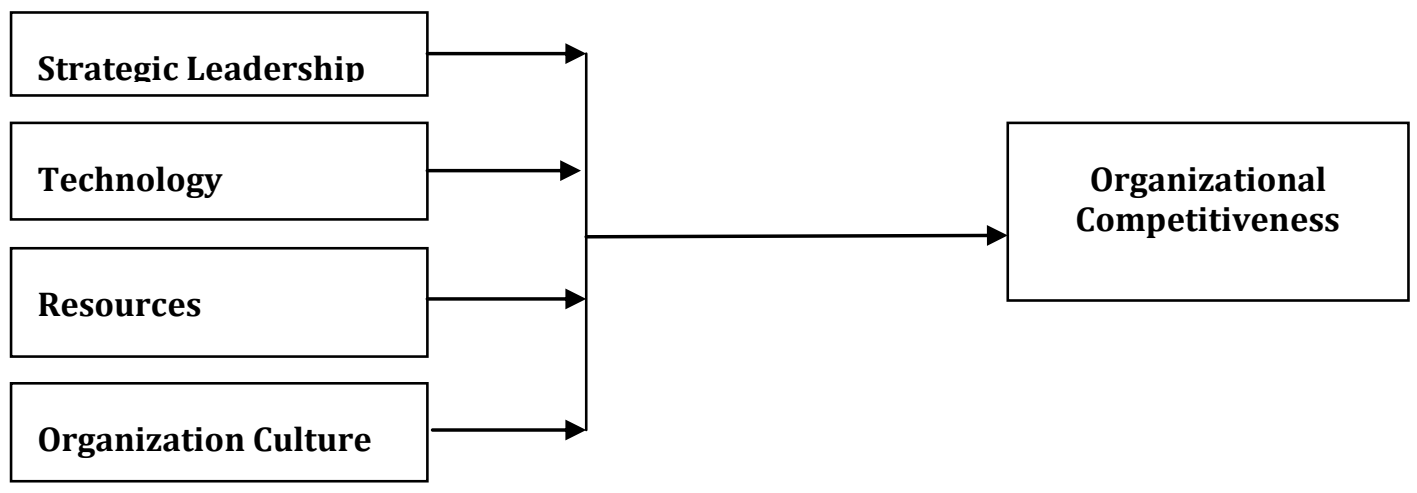

\section{Methodology}

Research Design: This study employed a descriptive research design. The choice of the descriptive survey design was based on the fact that in the study was interested on the state of affairs already existing in the field with respect to the variables of interest. This design was envisaged to help describe the way the factors such 
as strategic leadership, technology, resources and culture affect the organizational competitiveness according to the respondents.

Population and sampling: The target population for this study comprised of the Top 100 SMEs in Kenya. There are 79 SMEs from Nairobi County in the Top 100 SMEs. The sample size for this study was 25 SMEs which represented $30 \%$ of the target population as shown in Table 1 below. Stratified sampling was used to select the SMEs operating in Nairobi County. The stratus were the five categories; real estate, supplies, services, distribution and manufacturing. The study focused on top management employees who develop competitive strategies for the organization. Thus special interest was on the business development managers or any manager equivalent to the business development manager in the SMEs.

Table 1: Population and Sample Matrix

\begin{tabular}{lll}
\hline Category & Population & Sample Size \\
\hline Real Estate & 6 & 2 \\
Supplies & 24 & 7 \\
Services & 27 & 8 \\
Distribution & 8 & 3 \\
Manufacturing & 14 & 5 \\
Total & $\mathbf{7 9}$ & $\mathbf{2 5}$ \\
\hline
\end{tabular}

Data Collection Methods and analysis: In view of the advantages and the need to gather more information a combination of open and closed ended questionnaires were utilized as the main data collection tools. The questionnaire was structured into two parts; part I focusing on demographic information about respondents and the SMEs, while part II focused on information on the study variables (strategic leadership, adoption of technology, resources, organization culture and competitiveness). SPSS was used to aid in data processing (both descriptive and inferential statistics). Pearson correlation coefficient was used to show the relationship between the independent variables and the dependent variable.

\section{Results and Discussion}

Introduction: A response rate of $84 \%$ was achieved and this was considered acceptable. Of those who responded, 38\% were aged between 41 to 50 years, while 33\% were over 50 years and $29 \%$ were between 31 to 40 years of age. In terms of years of experience of the respondents, $47.6 \%$ had experience of between 5 10 years while $33.3 \%$ had worked between $1-5$ years and $19 \%$ had worked for over 10 years. This implies that the respondents had worked long enough in the organizations and thus were knowledgeable on the issues being addressed by the study. $47.6 \%$ of the respondents were general managers, $33.3 \%$ were operations manager and 19\% were business development managers. The findings imply that the respondents were in managerial level hence were involved in making critical decisions on issues regarding organizational competitiveness and ways of gaining competitive advantage among its competitors. Responses in terms of type of business indicated that $43 \%$ were private limited companies, $33 \%$ were in partnerships and $24 \%$ were public limited companies. On the area of management of the business, $52 \%$ are managed by owners. On the fronts of the years the business has been in operation, $66.7 \%$ of the businesses had been in operation for a period of between $5-10$ years, while $23.8 \%$ had been in existence for less than 5 years while $9.5 \%$ had been in operation for a period of 11-20 years. The findings imply that most of the companies are young and they are being established and thus the needs for them to relook at the factors that can help them thrive through the competitive environment.

Descriptive Analysis results: The first objective of the study was to determine the influence of strategic leadership on competitiveness of Small and Medium Enterprises in Nairobi County. $61.9 \%$ of the respondents 
indicated that leadership was a critical factor that enhances organizational competitiveness, $62 \%$ indicated that the leadership in their institution was effective in setting SMART goals and objectives for team members and $76.2 \%$ indicated that leaders in their institution have put in place a clear vision statement to guide the companies operation. Furthermore, $61.9 \%$ of the respondents indicated that leaders in their corporation motivate the employees to increase their productivity, while $66.7 \%$ agreed that leaders in their corporation always communicated about an achievable view of the future and another $66.7 \%$ agreed that leaders in their corporation inspired to set an example for employees to accomplish tasks in the organization. Finally $71.4 \%$ of the respondents agreed that leaders in their institution encouraged employees' participation and involvement in decision making process. On the extent to which strategic leadership influenced the SMEs competitiveness, $47.6 \%$ indicated that strategic leadership influences competitiveness to a great extent while $33.3 \%$ indicated to a very great extent and $19 \%$ indicated to a moderate extent. The study findings are in line with strategic leadership theory which according to (Hunt, 1991), the activities associated with strategic leadership include making strategic decisions, creating and communicating vision of the future, developing key competences and capabilities, developing organizational structures, processes and controls; sustaining effective organizational cultures and infusing ethical value systems into the organization.

The study examined the influence of technology on competitiveness of Small and Medium Enterprises in Nairobi County. $76.2 \%$ of the respondents indicated that adoption of technology had a significant correlation with organizational competitiveness, $61.9 \%$ indicated that technology advancement has significantly promoted market-like forms of production and distribution in their company and $61.9 \%$ indicated that adoption of technology promotes high levels of efficiency and performance within their organization. $76 \%$ of the respondents agreed that E-commerce was certainly a very effective tool when it comes to establishing customer relations and provision of access to global markets, $85.7 \%$ agreed that through technology their company has been able to increase the market size and market structure and $71.5 \%$ agreed that the Internet was helping them to enlarge their existing markets by cutting through many of the distribution and marketing barriers. In addition, $71.5 \%$ agreed that E-commerce lowers information and transaction costs for operating on overseas markets and providing a cheap and efficient way to strengthen customer-supplier relations while $76.2 \%$ agreed that technology has encouraged their company to develop innovative ways of advertising, delivering and supporting their marketing efforts. The study sought to determine the extent to which technology deployment affects competitiveness in organization. $42.9 \%, 38.1 \%$ and $19 \%$ of the respondents indicated that technology influenced competitiveness to a very high extent, a high extent and moderate extent respectively. This finding is in consistent with those of Mutula and Van Brakel (2006) who noted that ICTs, especially the internet, have a significant impact on the operations of SMEs by facilitating their access to global markets, enabling them to sell to international customers, and to compete favorably with large corporations.

In examining the influence of resources on competitiveness of Small and Medium Enterprises in Nairobi County was examined, $76.2 \%$ of the respondents agreed that they recognize human capital as crucial to the exploitation of business opportunities and $76.1 \%$ agreed that they evaluated their resources and capabilities and understood their value for the firm. In addition, $76.2 \%$ of the respondents agreed that they developed human resources which help in identifying and operating in markets while $71.4 \%$ agreed that they demonstrated timely responsiveness, rapid and flexible product/service innovation coupled with internal and external competencies. Of those who responded, $76.2 \%$ agreed that they had rare resources in their organization as compared to their competitors. Finally, $76.2 \%$ of the respondents agreed that they had nonsubstitutable resources in their organization amongst their potential competitors and another $71.4 \%$ agreed that they had non-imitable resources in their organization amongst their potential competitors. In terms of the extent to which availability of resources affect SMEs competitiveness, $7.6 \%, 42.9 \%$ and $9.5 \%$ of the respondents indicated that resource availability influenced their competitiveness to a very high extent, a high extent and moderate extent respectively. The study findings are in support of Resource-based view theory which claims that resources are tradable and thus transferable and imitable and that instead, capabilities are unique and the source of competitive advantage. Barney (2011) also found that resources include, among others, capital equipment, skills of individual employees, reputation, and brand names. On the influence of 
organization culture, $57.2 \%$ of the respondents agreed that their organization allowed employees to be innovative, $61.9 \%$ agreed that employees in their organizations are willing to experiment new things and 95.2\% agreed that employees in their organizations have high expectations for performance. $76.2 \%$ agreed that employees in their organization work in collaboration with others and $85.7 \%$ agreed that employees in their organizations have respect for individual rights. $85.7 \%$ of the respondents agreed that there is fairness in their organization. On customer centric perspective, $71.4 \%$ of the respondents agreed that their organizations are customer oriented and $76.2 \%$ agreed that their firms have shaped a customer responsive culture by hiring employees who are outgoing and friendly.

In comparison with competition, $85.7 \%$ of the respondents agreed that compared to their competitors in the previous year, their organization's sales growth rate was higher, $81 \%$ agreed that their organization's market share was bigger and $85.7 \%$ agreed that the level of employee productivity in their organization was higher. In furtherance, $76.1 \%$ of the respondents agreed that compared to the previous year, the level of profitability of their organization was higher while $76.2 \%$ of the respondents agreed that the company had experienced an increase in total revenue over the last 5 years and $66.6 \%$ agreed that compared to the previous year, their revenue flow was higher and increasing steadily. Finally, $61.9 \%$ of the respondents agreed that their firm's level of customer satisfaction had improved compared with their competitors and $76.2 \%$ agreed that the customers are loyal to their products and services and they rarely switch to new firms or competitors. The respondents were asked to indicate how their business had performed in the last four years in terms of market penetration level. $38.1 \%, 33.3 \%$ and $28.6 \%$ of the respondents indicated that in terms of penetration level their businesses had performed to a high extent, a very high extent and a moderate extent respectively. In regards to how the business performed in the last four years in terms of general product awareness level, $57.1 \%, 28.6 \%$ and $14.3 \%$ of the respondents indicated that their business had performed to a high extent, very high extent and moderate extent respectively.

Inferential Statistics analysis results: Bivariate analysis was carried out through cross tabulation to find out the relationship between demographic factors and the level of competitiveness amongst SMEs in Nairobi County. Demographic factors included age of the business, type of business and age bracket of the respondents. The results are presented in Table 2. Age of business was found to be statistically significant with the level of competitiveness $(\mathrm{P}=0.001)$. Comparing young businesses (less than 5 years) and old business (above 5 years), older business had a higher likelihood of being competitive as compared to the businesses less than 5 years old. Age bracket of the respondents was a significant factor to level of competitiveness $(\mathrm{P}=0.004)$. Aged (over 40 years) respondents had a higher likelihood of being competitive as compared to young managers, this could be attributed to by the experience and knowledge gained by older managers in comparison with younger managers. Type of business was not a significant factor to the level of competitiveness. The findings imply that all types of businesses whether partnerships or private limited companies can be competitive if correct measures are put in place to gain competitive advantage.

To establish whether there is a relationship between the study variables, Pearson product of moment's correlation coefficients was utilized. The results indicate that competitiveness and strategic leadership had a strong and significant positive relationship with a correlation coefficient of 0.819 . This finding is in agreement with those of Arham (2014) who investigated the impact of leadership behaviors on the performance of SMEs in Malaysia which revealed that: a) there were significant relationships between different leadership behaviors and organizational performance of services SMEs; and b) transformational leadership contributed more significantly to the performance of SMEs than transactional leadership behavior. This finding also corroborates with that of Ali, Elmi and Mohamed (2013) who investigated the relationship between leadership behavior and employee performance in Mogadishu, and concluded that there exists a statistically significant and positive relationship between leadership behavior and employee performance. The results also indicated that there exists a positive and significant $(\mathrm{r}=0.659$, $\mathrm{p}$-value $<0.001)$ correlation between competitiveness and adoption of technology. The findings are of relevance for SME successful implementation of IS particularly when we consider that Small and Medium Enterprises (SMEs) in Kenya has been targeted as a mechanism in generating domestic-led investment to stimulate economic development. 


$\begin{array}{r}\text { Journal of Economics and Behavioral Studies (ISSN: 2220-6140) } \\ \text { Vol. 9, No. 2, pp. 161-173, April } 2017 \\ \hline \hline\end{array}$

Table 2: Relationship between Demographics and Level of Competitiveness within SMES

\begin{tabular}{lllll}
\hline & & \multicolumn{2}{l}{ Level of competitiveness } & Chi-square \\
& & Low & High & \\
\hline Age of business & Less than 5 years & 5 & 0 & \\
& $5-10$ years & 1 & 13 & \\
\multirow{4}{*}{ Age bracket } & $11-20$ years & 1 & 1 & \\
& $31-40$ & 5 & 1 & \\
& $41-50$ & 0 & 8 & $\mathrm{X} 2=10.821(\mathrm{p}=0.004)$ \\
Type of business & 2 & 5 & \\
& Over 50 & 3 & 4 & $\mathrm{X} 2=0.429(\mathrm{p}=0.531)$ \\
\hline
\end{tabular}

Table 3: Bivariate Correlation analysis results

\begin{tabular}{lll}
\hline Variable & & Competitiveness \\
\hline Strategic leadership & Pearson Correlation & 0.819 \\
& Sig. (2-tailed) & 0.000 \\
Technology & Pearson Correlation & 0.659 \\
& Sig. (2-tailed) & 0.001 \\
Resources & Pearson Correlation & 0.795 \\
& Sig. (2-tailed) & 0.000 \\
Organization culture & Pearson Correlation & 0.635 \\
& Sig. (2-tailed) & 0.002 \\
\hline
\end{tabular}

Analysis results further indicated that resources and competitiveness had a positive and significant relationship ( $\mathrm{r}=0.795, \mathrm{p}$-value $<0.000)$. This finding mirrors that of Oliver (1997) who in examining sustainable competitive advantage from the institutional and resource-based views suggests that both resource capital and institutional capital are indispensable to sustainable competitive advantage. This finding is also in corroboration with that of Ngugi, Gakure, Were, Ngugi and Kibiru (2012) who examined the influence of intellectual capital and growth of small and medium enterprise in Kenya and concluded that management's technical skills influenced the growth of Small and Medium Enterprises. Analysis results also revealed the existence of a positive and significant relationship between organizational culture and competitiveness ( $\mathrm{r}=0.635$, $\mathrm{p}$-value $<0.002)$. This finding concurs with that of Ehtesham et al. (2011) whose study statistical analysis results revealed that involvement is highly correlated with consistency and adaptability. Similarly, the other dimensions of organizational culture have a positive significant relationship with the performance management practices. Leon (2010) also contends that organizational culture and leadership styles have a link and both play an important role in determining organizational effectiveness. The analysis results also is in tandem with the assertion by Shahzad et al. (2012) that if employees are committed and having the same norms and values as that of the organization, performance towards achieving the overall organization goals is enhanced. This finding also supports the assertion by Abdi and Senin (2014) that organization members with great experience and organizational culture enhances the performance of the organization. Based on the review of the existing literature, Abdi and Senin conclude that organizational culture plays a significant role in innovation. 


\section{Conclusion and Recommendations}

The study concludes that strategic leadership influenced organizational competitiveness. Sustainable competitive advantage of the firm stems from the effective strategic leaders. The commitment and enthusiasm of a strategic leader shapes the common goals of the organization and provides inspiration and motivation for people to perform even better. The study also concludes that technology influences organizational competitiveness by increasing internal efficiencies and promoting better handling of the external environment through us of use of electronic marketing and e-commerce to improve sales, reduce cost and increase overall business efficiency and hence this help firms in gaining competitive advantage by ensuring low cost and high quality products. Study findings also reveal that an organizational internal resource has a positive influence on the competitiveness of Small and Medium Enterprises in Nairobi County. Finally the study concludes that organization culture significantly related to competitiveness.

Based on the study findings, SMEs should embrace various competitive strategies to remain relevant in the market and achieve the required competitiveness. The SMEs and players in the sector should pursue deliberate efforts to enhance leadership effectiveness through appropriate exposure, leadership training and development initiatives. SMEs owners and managers should be encouraged to embrace appropriate innovations and technology towards realizing higher levels of efficiency and effectiveness in the areas of product design, product delivery and customer service. We also suggest that SMEs should ensure effectiveness and efficiency in development, prioritization and optimal utilization of available resources. Additionally, as in other firms, SMEs in Kenya need to develop, nurture and cultivate an innovative and entrepreneur culture as an avenue to enhancing firm competitiveness. This culture can be strengthened through establishment of incubation and mentorship centres across the country. This study focused on the factors influencing organizational competitiveness of small and medium enterprises within Nairobi County, Kenya. Other studies could be pursued in terms of expanding the geographical setting and taking recognition of other variables that could intervene and or moderate the relationship being investigated.

\section{References}

Abdi, K. \& Senin, A. A. (2014). Investigation on the Impact of Organizational Culture on Organization Innovation. Journal of Management Policies and Practices, 2(2) 1-10.

Abishua, D. A. (2010). Strategies used by Equity Bank to Compete in the Kenyan Banking Industry; Unpublished MBA Project, School of Business, University of Nairobi

Adeosun, O., Adeosun, T. \& Adetunde, I. (2009). Strategic Application of Information and Communication Technology for Effective Service Delivery in Banking Industry. Journal of Social Sciences, 3, 47-51.

Ainuddin, R. A., Beamish, P. W., Hulland, J. S. \& Rouse, M. J. (2007). Resource attributes and firm performance in international joint ventures. Journal of World Business, 42, 47-60.

Ali, A. M., Elmi, H. O. \& Mohamed, A. I. (2013). The Effect of Leadership Behaviors on Staff Performance in Somalia. Educational Research International, (2) 2.

Ambrosini, V., Bowman, C. \& Collier, N. (2009). Dynamic Capabilities: An Exploration of How Firms Renew Their Resource Base. British Journal of Management, 20(1), 9-24.

Amit, R. \& Schoemaker, P. J. (1993). Strategic Assets and Organizational Rent. Journal of Strategic Management, 14(1), 33-46.

Arham, A. F. (2014). Leadership and Performance: the Case of Malaysian SMEs in the Services Sector. International Journal of Asian Social Science, 4(3), 343-355.

Aremu, M. A. \& Adeyemi, S. L. (2011). Small and Medium Scale Enterprises as A Survival Strategy for Employment Generation in Nigeria. Journal of Sustainable Development, 4(1), 200-206.

Barney, J. B. (1991). Firm resources and sustained competitive advantage. Journal of Management, 17(1), 99120.

Barney, J. B. (1995). Looking inside for competitive advantage. Academy of Management, Executive, 9 (4), 4961. 
Barney, J. B. (2011). Firm resources and sustained competitive advantage. Journal of Management, 17(1), 99120.

Boal, K. B. \& Hooijberg, R. (2001). Strategic Leadership Research: Moving On. The Leadership Quarterly 11 (4), 515-549

Brynjolffson, E. \& Hitt, L. (1996). Paradox lost? Firm-level Evidence on the Returns to Information Systems Spending. Management Science, 4, 541-558.

Buhalis, D. (2004). e-Airlines: Strategic and Tactical use of ICT in the Airline Industry. Information and Management, 41(7), 805-825.

Caldwell, D. (2013). Mid-size companies show real pulse of economy. Retrieved from http://www.usatoday.com/story/money/business/2013/02/24/medium-size-companiescnbc/1938679/ on $5^{\text {th }}$ April, 2016.

Chittithaworn, C., Islam, M. A., Keawchana, T. \& Yusuf, D. H. M. (2011). Factors Affecting Business Success of Small \& Medium Enterprises (SMEs) in Thailand. Asian Social Science, 7(5), 180.

Connor, T. (2002). The Resource-Based View of Strategy and its Value to Practicing Managers'. Strategic Change, (11), 307-316.

Day, G. (1994). The Capability of Market-Driven Organizations. Journal of Marketing, 58, 37-52.

Ehtesham, U. M., Muhammad, T. M. \& Muhammad, S. A. (2011). Relationship between organizational culture and performance management practices: A Case of University in Pakistan. Journal of Competitiveness, $4,78-86$

Garelli, S. (2006). Competitiveness of Nations: The Fundamentals. IMD World Competitiveness Yearbook.

Grant, R. M. (1991). The Resource-Based Theory of Competitive Advantage: Implications for Strategy Formulation. Knowledge and Strategy, 33(3), 3-23.

Grant, R. M. (2011). The Resource-based Theory of Competitive Advantage: Implications for Strategy Formulation, California

Hakansson, H. \& Snehota, I. (1989). No business is an island: The network concept of business strategy. Scandinavian Journal of Management, 5(3), 187-200

Hunt, S. \& Derozier, C. (2004). The Normative Imperatives of Business and Marketing Strategy: Grounding Strategy in Resource-Advantage Theory. Journal of Business \& Industrial Marketing, 19(1), 5-22.

Hunt, S. D. (1991). Modern Marketing Theory: Critical Issues in the Philosophy of Marketing Science, Cincinnati: South Western Publishing Co.

Ireland, R. D. \& Hitt, M. A. (1999). Achieving and Maintaining Strategic Competitiveness in the 21 ${ }^{\text {st }}$ Century: The Role of Strategic Leadership. Academy of Management Executive, 13(1), 43-57.

Kay, J. (2000). Strategy and the Delusion of Grand Designs', pp. 5-10 in Dickson, T. (ed) Mastering Strategy. London: Financial Times/Prentice-Hall.

Kaplan, R. S. \& Norton, D. P. (2001). The Strategy-Focused Organization: How Balanced Scorecard Companies Thrive in the New Competitive Environment, Boston: HBS Press

Koech, P. \& Namusunge, G. S. (2012). Effect of leadership styles on organization performance at State Corporation in Kenya. International Journal of Business and Commerce, 2(1), 1-12.

Kostopoulos, K., Spanos, Y. E. \& Prastacos G. P. (2002) 'The Resource-Based View of the Firm and Innovation: Identification of Critical Linkages, The 2nd European Academy of Management Conference, Stockholm.

Leon, P. (2010). Leadership and trust: Their effect on knowledge sharing and team performance. Management learning.

Manochehri, N., Al-Esmail, R. \& Ashrafi, R. (2012). Examining the Impact of Information and Communication Technologies (ICT) on Enterprise Practices: A Preliminary Perspective from Qatar. The Electronic Journal of Information Systems in Developing Countries, 51(3).

Mutula S. M. \& van Brakel, P. (2006). E-readiness of SMEs in the ICT sector in Botswana with respect to information access. The Electronic Library, 3, 402-17.

Ngugi, J. K., Gakure, R. W., Were, M. S., Ngugi, P. K. \& Kibiru, C. R. (2012). The Influence of Intellectual Capital on the Growth of Small and Medium Enterprises in Kenya. Journal of Business Management and Corporate Affairs, 1(1)11-19. 
Nzitunga, J. B. (2015). Strategic Development for Manufacturing Small \& Medium Enterprises (SMEs) in Namibia. Management, 5(4) 117-131

OECD. (2004). The Economic Impact of ICT Measurement, Evidence and Implication Organization for Economic Co-operation and Development. Paris: OECD.

Oliver, C. (1997). Sustainable Competitive Advantage: Combining Institutional and Resource-Based views. Strategic Management Journal, 18(9), 697-71

Ollo-Lopez A. \& Aramendia-Muneta, M. E. (2012). ICT Impact on Competitiveness, Innovation and Environment. Telematics and Informatics, 6, 204-210.

Penrose, E. T. (1959). The Theory of the Growth of the Firm. Oxford, UK: Oxford University Press.

Peteraf, M. A. (1993). The Cornerstones of Competitive Advantage: A Resource-Based View, Strategic Management Journal, 14(3), 179-191.

Porter, M. E. (1985). Competitive Advantage: Creating and Sustaining Superior Performance. New York: Free Press.

Qiuhong, J. \& Tiorini, A. (2009). Strategic Management in East Asia SMEs: The Case Study of SMEs in China and Indonesia.

Ray, G., Barney, J. B. \& Muhanna, W. A. (2004). Capabilities, Business Processes, and Competitive Advantage: Choosing the Dependent Variable in Empirical Tests of the Resource-Based View: Strategic Management Journal, 25, 23-37

Ramsey, E., Ibbotson, P., Bell, J. \& Gray, B. (2003). E-opportunities of service sector SMEs: an Irish crossborder study. Journal of Small Business and Enterprise Development, 10(3), 250-64.

Republic of Kenya. (2009). Economic Survey. Nairobi: Government Printer.

Republic of Kenya. (2012). Economic Survey. Nairobi: Government Printer.

Rogers, E. M. (1995). Lessons for Guidelines from the Diffusion of Innovations. The Joint Commission journal on quality improvement, 21(7), 324.

Rogers, E. M. (2003). Diffusion of Innovation (4th. Edition). New York: Free Press.

Shahzad, F., Luqman, R. A., Khan, A. R. \& Shabbir, L. (2012). Impact of Organizational Culture on Organizational Performance: An Overview. Interdisciplinary Journal of Contemporary Research in Business, 3(9).

Shafie, B., Baghersalimi, S. \& Barghi, V. (2013). The Relationship between Leadership Style and Employee Performance: A Case Study of Real Estate Registration Organization of Tehran Province. Singapore Journal of Business Economics and Management Studies, 2(5), 21-29.

Schein, E. H. (2010). Organizational culture and leadership. John Wiley \& Sons.

Selznick, P. (1984). Leadership in Administration. Berkeley, CA: University of California Press (Originally published 1957).

Thompson, A., Strickland, A. J. \& Gamble, J. (2012). Crafting and Executing Strategy: The Quest for Competitive Advantage: Concepts and Cases. McGraw-Hill

Wernerfelt, B. (1984). A Resource-Based View of The Firm. Strategic Management Journal, 5(2), 171-180.

Williamson, P. J. (2009). Strategy as options in the future. Sloan Management Review, 3 (40), 117-127.

Zumitzavan, V. \& Udchachone, S. (2014). The Influence of Leadership Styles on Organizational Performance Mediated by Organizational Innovation: A Case Study of the Hospitality Industry in Thailand. International Conference on Economics, Management and Development, 45-52. 